\title{
Dietary intake of Indians living in the metropolitan area of Durban
}

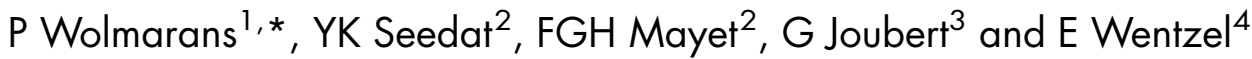 \\ ${ }^{1}$ Medical Research Council, National Research Programme for Nutritional Intervention, PO Box 19070, \\ Tygerberg 7505, South Africa: ${ }^{2}$ University of Natal, Faculty of Medicine, Department of Medicine, \\ PO Box 17039, Congella 4013, South Africa: ${ }^{3}$ University of the Orange Free State, Department of Biostatistics, \\ PO Box 339 (G31), Bloemfontein 9300, South Africa: ${ }^{4}$ Previously from the University of the Western Cape, \\ Faculty of Community and Health Sciences, Department of Human Ecology and Dietetics, P/Bag X17, \\ Bellville 7535, South Africa
}

Submitted 21 September 1998: Accepted 2 November 1998

\begin{abstract}
Objective: To report on energy and nutrient intakes, as a risk factor for coronary heart disease in Indian South Africans.

Design: Cross-sectional dietary study as part of a coronary heart disease survey.

Setting: Metropolitan area of Durban, South Africa.

Subjects: Free-living Indian men $(n=406)$ and women $(n=370) 15-69$ years of age. Methodology: Dietary data were collected by three interviewers using a 24-h dietary recall and expressed as median intakes of macronutrients.

Results: Results reported a low energy intake and the percentage of energy derived from total fat varied between 32.3 and $34.9 \%$ in men and between 33.1 and $36.1 \%$ in women. The energy intake to basal metabolic rate (EI : BMR) ratios were low for all age groups suggesting potential under-reporting. Intake of polyunsaturated fatty acids was high, more than $10 \%$ of energy, with a median polyunsaturated to saturated fatty acid ratio (P : S ratio) that varied between 1.38 and 1.96 for the various age and sex groups. Dietary cholesterol varied between 66 and $117 \mathrm{mg}$ per $4.2 \mathrm{MJ}$ in men and between 76 and $109 \mathrm{mg}$ per $4.2 \mathrm{MJ}$ in women. Dietary fibre intakes were low and varied between 8.0 and $11.0 \mathrm{~g}$ per $4.2 \mathrm{MJ}$ in men and between 7.6 and $9.6 \mathrm{~g}$ per $4.2 \mathrm{MJ}$ in women.

Conclusions: The dietary P : S ratios were high and the effect of such a high P : S ratio on the oxidation of low density lipoprotein in this population, with a high prevalence of coronary heart disease (CHD), should be investigated as a possible risk factor for CHD.
\end{abstract}

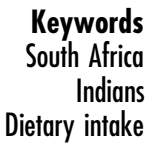

Keywords Indians Dietary intake
In South Africa coronary heart disease (CHD) is by far the most important cause of death among the white and Asian population in the category of diseases of the circulatory system, and indeed it is the most important of all causes of death. In 1985 the annual age-specific mortality rates from CHD were 178/100,000 and 110/ 100,000 for white and Indian South Africans, respectively, and surpass by far that of a population of Euro-African-Malay descent (so-called 'coloured' population $)(60 / 100,000)^{1}$. Black people had a minimal annual age-specific mortality rate from CHD, of 4/ $100,000^{1}$. In the UK the proportional mortality ratio (number of deaths) in South Asians, for the years 197078, was 121 for males and 118 for females ${ }^{2}$. There is variation in the patterns of mortality between different ethnic groups, for example the Punjabis, Gujaratis, Moslems and Southerners ${ }^{3}$. Regional variations in CHD has also been noted in India ${ }^{4}$. In the 1960s two population-based studies showed that the prevalence of $\mathrm{CHD}$ was low. In one study ${ }^{5}$ on the general population 11 of the 1046 (1.04\%) individuals older than 25 years of age who were studied, had CHD while in another random population survey in Delhi, 17 of the $1642(1.03 \%)$ persons studied had $\mathrm{CHD}^{6}$. Recent information from India showed, however, a prevalence of 96.7/1000 (based on clinical and electrocardiographic criteria) in urban areas and 74/1000 (evaluated by Rose questionnaire and electrocardiogram) in urbanized rural areas ${ }^{7}$.

The major risk factors for CHD observed in Indian South Africans were hypercholesterolaemia, hypertension, obesity (in women), smoking (in men) ${ }^{8}$ and diabetes mellitus ${ }^{9}$. A study showed that $20 \%$ of Indian South Africans had hypercholesterolaemia while hypertension was found in 19\% and diabetes mellitus in $16 \%{ }^{8}$. Diet plays an important role in all of these risk factors for CHD. CHD is also a major cause of death in white and 'coloured' South Africans. Studies in the Western Cape have shown that these people follow a Western type of diet which is high in total fat and 
cholesterol and low in fibre, with a polyunsaturated to saturated fatty acid ratio ( $\mathrm{P}: \mathrm{S}$ ratio) that varied between 0.48 and $1.00^{10,11}$. Since little is known about the dietary intake of Indian South Africans a dietary study was part of the investigations in the CHD survey undertaken on Indians living in the metropolitan area of Durban ${ }^{8}$. The aim of this article is therefore to report on nutrient intakes as possible risk factors for CHD in Indian South Africans.

\section{Subjects and methods}

The dietary study formed part of the coronary risk factor survey in the metropolitan area of Durban, Natal, and the sample selection for this study has been described in more detail by Seedat et al. ${ }^{8}$ At the time of the study Durban was still divided into zones set aside for specific ethnic groups and the Indian areas were scattered throughout Durban. Information on the total Indian population of metropolitan Durban and that for each residential area were determined by the 1980 population census figures. The latter information, as well as the number of dwellings in each area, were obtained from the various municipalities included in metropolitan Durban. Using the number of dwellings and the population in each area, a fixed percentage population of $0.24 \%$ per area was selected for the study. Men $(n=406)$ and women $(n=370)$ who participated in the study were between the ages of 15 and 69 years and were permanent residents within the geographical area of metropolitan Durban. The exclusion criteria were: pregnancy and lactation, being bed-ridden, mental retardation, carcinoma and tuberculosis therapy.

The latest ratepayers' and electricity consumers' records were used for random selection of household addresses. One member of the family at each address was selected randomly for participation in the survey. The study started in May 1984 and was completed over a 2-year period.

A medical practitioner was trained by two senior dietitians from the Medical Research Council in the collection of dietary intake, using the same technique as for the Coronary Risk Factor Study (CORIS) ${ }^{10}$. This medical practitioner was responsible for the training of the fieldworkers who collected the data in the study on Indian South Africans. Food models, household measures and prepared dishes were used in the training programme to standardize the research workers' assessment of food portion size.

Each household randomly selected for the study, was visited on at least three occasions and during the second visit information on dietary intake was

Table 1 Total Els, energy distribution of macronutrients and nutrient ratios: Indian South African men

\begin{tabular}{|c|c|c|c|c|c|c|}
\hline Age (years) & & $\begin{array}{c}15-24 \\
(n=107)\end{array}$ & $\begin{array}{c}25-34 \\
(n=91)\end{array}$ & $\begin{array}{c}35-44 \\
(n=94)\end{array}$ & $\begin{array}{c}45-54 \\
(n=69)\end{array}$ & $\begin{array}{c}55-69 \\
(n=45)\end{array}$ \\
\hline Energy (MJ) & $\begin{array}{l}\text { Mean (SD) } \\
\text { Median } \\
Q_{1}-Q_{3}\end{array}$ & $\begin{array}{c}8.4(2.9) \\
8.3 \\
6.4-10.1\end{array}$ & $\begin{array}{c}8.1(3.0) \\
7.7 \\
6.5-10.0\end{array}$ & $\begin{array}{c}8.5(2.8) \\
8.1 \\
6.4-10.7\end{array}$ & $\begin{array}{c}8.1(3.5) \\
7.6 \\
5.5-10.2\end{array}$ & $\begin{array}{c}5.6(1.9) \\
5.7 \\
3.8-6.7\end{array}$ \\
\hline Protein (\%E) & $\begin{array}{l}\text { Median } \\
Q_{1}-Q_{3}\end{array}$ & $\begin{array}{c}12.7 \\
10.1-15.9\end{array}$ & $\begin{array}{c}13.8 \\
11.6-17.9\end{array}$ & $\begin{array}{c}12.3 \\
9.1-15.7\end{array}$ & $\begin{array}{c}13.1 \\
9.8-16.9\end{array}$ & $\begin{array}{c}12.2 \\
9.9-15.4\end{array}$ \\
\hline Animal protein $(\% \mathrm{E})$ & $\begin{array}{l}\text { Median } \\
Q_{1}-Q_{3}\end{array}$ & $\begin{array}{c}7.2 \\
3.5-11.3\end{array}$ & $\begin{array}{c}9.3 \\
5.2-13.3\end{array}$ & $\begin{array}{c}6.7 \\
2.8-10.7\end{array}$ & $\begin{array}{c}8.1 \\
4.2-12.4\end{array}$ & $\begin{array}{c}6.7 \\
3.0-10.0\end{array}$ \\
\hline Plant protein $(\% \mathrm{E})$ & $\begin{array}{l}\text { Median } \\
Q_{1}-Q_{3}\end{array}$ & $\begin{array}{c}5.0 \\
4.0-6.3\end{array}$ & $\begin{array}{c}4.8 \\
3.9-6.1\end{array}$ & $\begin{array}{c}5.0 \\
3.9-6.6\end{array}$ & $\begin{array}{c}5.0 \\
3.8-6.3\end{array}$ & $\begin{array}{c}5.8 \\
4.7-7.6\end{array}$ \\
\hline Total fat (\%E) & $\begin{array}{l}\text { Median } \\
Q_{1}-Q_{3}\end{array}$ & $\begin{array}{c}34.6 \\
28.4-41.5\end{array}$ & $\begin{array}{c}33.3 \\
27.4-38.4\end{array}$ & $\begin{array}{c}33.2 \\
26.3-40.7\end{array}$ & $\begin{array}{c}35.9 \\
27.5-40.9\end{array}$ & $\begin{array}{c}36.6 \\
26.6-42.1\end{array}$ \\
\hline Saturated fat (\%E) & $\begin{array}{l}\text { Median } \\
Q_{1}-Q_{3}\end{array}$ & $\begin{array}{c}9.1 \\
5.9-11.8\end{array}$ & $\begin{array}{c}9.4 \\
6.7-11.8\end{array}$ & $\begin{array}{c}8.4 \\
5.9-11.5\end{array}$ & $\begin{array}{c}8.7 \\
6.3-11.1\end{array}$ & $\begin{array}{c}7.8 \\
5.0-11.5\end{array}$ \\
\hline Monounsaturated fat (\%E) & $\begin{array}{l}\text { Median } \\
\mathrm{Q}_{1}-\mathrm{Q}_{3}\end{array}$ & $\begin{array}{c}9.6 \\
7.6-11.9\end{array}$ & $\begin{array}{c}9.6 \\
7.3-12.5\end{array}$ & $\begin{array}{c}9.6 \\
6.7-11.8\end{array}$ & $\begin{array}{c}9.4 \\
7.5-11.7\end{array}$ & $\begin{array}{c}8.9 \\
5.9-11.4\end{array}$ \\
\hline Polyunsaturated fat (\%E) & $\begin{array}{l}\text { Median } \\
Q_{1}-Q_{3}\end{array}$ & $\begin{array}{c}11.7 \\
9.0-14.6\end{array}$ & $\begin{array}{c}9.5 \\
6.9-12.9\end{array}$ & $\begin{array}{c}10.2 \\
8.4-14.5\end{array}$ & $\begin{array}{c}11.0 \\
8.1-15.5\end{array}$ & $\begin{array}{c}12.5 \\
9.0-16.9\end{array}$ \\
\hline$P$ : S ratio & $\begin{array}{l}\text { Median } \\
\mathrm{Q}_{1}-\mathrm{Q}_{3}\end{array}$ & $\begin{array}{c}1.40 \\
0.87-2.24\end{array}$ & $\begin{array}{c}1.09 \\
0.72-1.76\end{array}$ & $\begin{array}{c}1.38 \\
0.82-2.16\end{array}$ & $\begin{array}{c}1.36 \\
0.89-1.96\end{array}$ & $\begin{array}{c}1.77 \\
1.10-2.73\end{array}$ \\
\hline Cholesterol (mg per 4.2 MJ) & $\begin{array}{l}\text { Median } \\
\mathrm{Q}_{1}-\mathrm{Q}_{3}\end{array}$ & $\begin{array}{c}98 \\
40-169\end{array}$ & $\begin{array}{c}117 \\
57-177\end{array}$ & $\begin{array}{c}77 \\
30-174\end{array}$ & $\begin{array}{c}92 \\
47-144\end{array}$ & $\begin{array}{c}66 \\
41-140\end{array}$ \\
\hline Carbohydrate (\%E) & $\begin{array}{l}\text { Median } \\
\mathrm{Q}_{1}-\mathrm{Q}_{3}\end{array}$ & $\begin{array}{c}50.0 \\
42.8-57.8\end{array}$ & $\begin{array}{c}49.7 \\
43.1-57.5\end{array}$ & $\begin{array}{c}49.3 \\
39.6-56.4\end{array}$ & $\begin{array}{c}45.5 \\
37.1-53.8\end{array}$ & $\begin{array}{c}45.6 \\
41.9-55.4\end{array}$ \\
\hline Sugar (\%E) & $\begin{array}{l}\text { Median } \\
Q_{1}-Q_{3}\end{array}$ & $\begin{array}{c}15.8 \\
9.0-21.4\end{array}$ & $\begin{array}{c}15.8 \\
10.1-22.6\end{array}$ & $\begin{array}{c}13.5 \\
9.1-19.2\end{array}$ & $\begin{array}{c}11.2 \\
7.4-21.4\end{array}$ & $\begin{array}{c}10.8 \\
5.4-13.4\end{array}$ \\
\hline Fibre (g per $4.2 \mathrm{MJ}$ ) & $\begin{array}{l}\text { Median } \\
Q_{1}-Q_{3}\end{array}$ & $\begin{array}{c}8.0 \\
5.9-10.5\end{array}$ & $\begin{array}{c}8.2 \\
5.8-11.1\end{array}$ & $\begin{array}{c}8.6 \\
6.0-11.6\end{array}$ & $\begin{array}{c}8.0 \\
6.0-10.9\end{array}$ & $\begin{array}{c}11.0 \\
7.2-15.3\end{array}$ \\
\hline
\end{tabular}

$\mathrm{Q}_{1}=25$ th percentile; $\mathrm{Q}_{3}=75$ th percentile. 
collected $^{8}$. Three interviewers were responsible for collecting the dietary information by means of a $24-\mathrm{h}$ recall. Information was collected on all food and liquids (except water) consumed during the day that preceded the interview unless the day was unusual in terms of dietary intake. If, for example, the respondent fasted on the previous day the 24-h dietary recall for the day before that was recorded. In order to help the respondents to remember what was eaten they were asked to relate all events of the day from the time they woke up until they went to bed. Standard measures, e.g. teaspoons, tablespoons, standard cup measures, large serving spoons and ladles, were used for estimating the size of the helping of food consumed. Portion sizes were also reported in terms of dimensions, e.g. for meat. Fruits and vegetables were graded into small, medium and large sizes. The second edition of the National Research Institute for Nutritional Diseases (NRIND Food Composition Tables) ${ }^{12}$ were used for computer coding the dietary data for the type of food eaten. In the case of typical Indian dishes where the quantity of individual ingredients were uncertain, these dishes were prepared by the interviewers according to the recipe provided by the respondents and the quantity of each ingredient used was determined. This information was used to calculate the nutritional composition of a recipe and a new food item was added to the food composition tables with its own food code. The food intake was coded in accordance with the NRIND Food Composition Tables ${ }^{12}$ and statistically analysed.

The SAS software package on mainframe computer, linked to the NRIND Food Composition Tables ${ }^{12}$, was used for analyses of the dietary data. Dietary intakes were summarized by medians and 25th and 75th percentiles, since the data had skew distributions. For comparison with other studies mean energy intakes are reported with SDs. Macronutrients are expressed as a percentage of total energy intake while dietary cholesterol and dietary fibre intakes are expressed per 4.2 MJ. Basal metabolic rate (BMR) was estimated with the equations of Schofield $(1985)^{13}$, using the mean weight $(\mathrm{kg})$ and mean height (m) (YK Seedat et. al., unpublished data), for the different age and sex categories and the energy intake to BMR (EI : BMR) ratios were calculated ${ }^{14}$.

\section{Results}

Descriptive statistics for energy, macronutrient and cholesterol intakes are given in Table 1 for men and in

Table 2 Total Els, energy distribution of macronutrients and nutrient ratios: Indian South African women

\begin{tabular}{|c|c|c|c|c|c|c|}
\hline Age (years) & & $\begin{array}{c}15-24 \\
(n=69)\end{array}$ & $\begin{array}{c}25-34 \\
(n=79)\end{array}$ & $\begin{array}{c}35-44 \\
(n=103)\end{array}$ & $\begin{array}{c}45-54 \\
(n=75)\end{array}$ & $\begin{array}{l}55-69 \\
(n=44)\end{array}$ \\
\hline Energy (MJ) & $\begin{array}{l}\text { Mean (SD) } \\
\text { Median } \\
\mathrm{Q}_{1}-\mathrm{Q}_{3}\end{array}$ & $\begin{array}{c}6.7(2.9) \\
6.1 \\
4.9-7.6\end{array}$ & $\begin{array}{c}5.8(2.2) \\
5.3 \\
4.4-6.6\end{array}$ & $\begin{array}{c}5.6(1.8) \\
5.7 \\
4.3-6.8\end{array}$ & $\begin{array}{c}5.4(1.9) \\
5.4 \\
4.2-6.6\end{array}$ & $\begin{array}{c}5.0(1.8) \\
4.7 \\
3.7-6.0\end{array}$ \\
\hline Protein (\%E) & $\begin{array}{l}\text { Median } \\
\mathrm{Q}_{1}-\mathrm{Q}_{3}\end{array}$ & $\begin{array}{c}13.5 \\
10.8-16.6\end{array}$ & $\begin{array}{c}13.3 \\
10.3-17.7\end{array}$ & $\begin{array}{c}13.6 \\
9.7-16.7\end{array}$ & $\begin{array}{c}13.0 \\
9.8-15.7\end{array}$ & $\begin{array}{c}11.9 \\
9.2-15.3\end{array}$ \\
\hline Animal protein (\%E) & $\begin{array}{l}\text { Median } \\
\mathrm{Q}_{1}-\mathrm{Q}_{3}\end{array}$ & $\begin{array}{c}8.7 \\
4.7-12.0\end{array}$ & $\begin{array}{c}8.6 \\
3.2-13.1\end{array}$ & $\begin{array}{c}7.7 \\
2.8-12.0\end{array}$ & $\begin{array}{c}6.9 \\
2.5-10.9\end{array}$ & $\begin{array}{c}6.0 \\
3.4-9.7\end{array}$ \\
\hline Plant protein (\%E) & $\begin{array}{l}\text { Median } \\
\mathrm{Q}_{1}-\mathrm{Q}_{3}\end{array}$ & $\begin{array}{c}5.1 \\
3.7-6.1\end{array}$ & $\begin{array}{c}5.3 \\
3.8-6.9\end{array}$ & $\begin{array}{c}5.5 \\
4.0-6.8\end{array}$ & $\begin{array}{c}5.5 \\
4.1-7.1\end{array}$ & $\begin{array}{c}5.5 \\
4.5-6.8\end{array}$ \\
\hline Total fat (\%E) & $\begin{array}{l}\text { Median } \\
\mathrm{Q}_{1}-\mathrm{Q}_{3}\end{array}$ & $\begin{array}{c}36.9 \\
31.1-40.5\end{array}$ & $\begin{array}{c}34.8 \\
29.7-40.3\end{array}$ & $\begin{array}{c}36.0 \\
29.4-42.0\end{array}$ & $\begin{array}{c}32.8 \\
26.9-39.1\end{array}$ & $\begin{array}{c}34.0 \\
26.5-38.9\end{array}$ \\
\hline Saturated fat (\%E) & $\begin{array}{l}\text { Median } \\
\mathrm{Q}_{1}-\mathrm{Q}_{3}\end{array}$ & $\begin{array}{c}9.8 \\
6.7-12.5\end{array}$ & $\begin{array}{c}9.0 \\
6.7-10.4\end{array}$ & $\begin{array}{c}8.5 \\
6.1-11.5\end{array}$ & $\begin{array}{c}7.0 \\
5.1-9.8\end{array}$ & $\begin{array}{c}8.2 \\
5.5-10.5\end{array}$ \\
\hline Monounsaturated fat (\%E) & $\begin{array}{l}\text { Median } \\
\mathrm{Q}_{1}-\mathrm{Q}_{3}\end{array}$ & $\begin{array}{c}10.9 \\
8.4-13.0\end{array}$ & $\begin{array}{c}9.9 \\
7.6-11.7\end{array}$ & $\begin{array}{c}9.6 \\
7.2-11.8\end{array}$ & $\begin{array}{c}8.3 \\
6.1-11.6\end{array}$ & $\begin{array}{c}9.1 \\
6.0-10.5\end{array}$ \\
\hline Polyunsaturated fat (\%E) & $\begin{array}{l}\text { Median } \\
Q_{1}-Q_{3}\end{array}$ & $\begin{array}{c}11.3 \\
8.1-14.9\end{array}$ & $\begin{array}{c}11.7 \\
9.7-15.0\end{array}$ & $\begin{array}{c}12.4 \\
9.7-15.7\end{array}$ & $\begin{array}{c}12.5 \\
9.4-15.5\end{array}$ & $\begin{array}{c}11.6 \\
8.8-15.5\end{array}$ \\
\hline$P: S$ ratio & $\begin{array}{l}\text { Median } \\
Q_{1}-Q_{3}\end{array}$ & $\begin{array}{c}1.26 \\
0.73-2.22\end{array}$ & $\begin{array}{c}1.38 \\
0.91-2.21\end{array}$ & $\begin{array}{c}1.55 \\
1.02-2.28\end{array}$ & $\begin{array}{c}1.64 \\
1.26-2.87\end{array}$ & $\begin{array}{c}1.49 \\
1.12-2.15\end{array}$ \\
\hline Cholesterol (mg per 4.2 MJ) & $\begin{array}{l}\text { Median } \\
Q_{1}-Q_{3}\end{array}$ & $\begin{array}{c}108 \\
52-183\end{array}$ & $\begin{array}{c}109 \\
39-168\end{array}$ & $\begin{array}{c}78 \\
33-159\end{array}$ & $\begin{array}{c}76 \\
29-174\end{array}$ & $\begin{array}{c}84 \\
36-192\end{array}$ \\
\hline Carbohydrate (\%E) & $\begin{array}{l}\text { Median } \\
\mathrm{Q}_{1}-\mathrm{Q}_{3}\end{array}$ & $\begin{array}{c}48.6 \\
40.7-55.0\end{array}$ & $\begin{array}{c}48.8 \\
41.6-54.7\end{array}$ & $\begin{array}{c}49.1 \\
40.9-57.3\end{array}$ & $\begin{array}{c}53.0 \\
43.1-58.2\end{array}$ & $\begin{array}{c}50.4 \\
46.4-60.4\end{array}$ \\
\hline Sugar (\%E) & $\begin{array}{l}\text { Median } \\
\mathrm{Q}_{1}-\mathrm{Q}_{3}\end{array}$ & $\begin{array}{c}14.2 \\
9.7-20.9\end{array}$ & $\begin{array}{c}13.4 \\
9.4-21.0\end{array}$ & $\begin{array}{c}13.8 \\
9.1-17.8\end{array}$ & $\begin{array}{c}11.6 \\
7.7-19.0\end{array}$ & $\begin{array}{c}11.4 \\
7.2-17.4\end{array}$ \\
\hline Fibre (g per $4.2 \mathrm{MJ}$ ) & $\begin{array}{l}\text { Median } \\
\mathrm{Q}_{1}-\mathrm{Q}_{3}\end{array}$ & $\begin{array}{c}7.6 \\
5.7-10.6\end{array}$ & $\begin{array}{c}8.9 \\
6.3-12.0\end{array}$ & $\begin{array}{c}8.9 \\
7.2-11.8\end{array}$ & $\begin{array}{c}9.3 \\
7.4-12.7\end{array}$ & $\begin{array}{c}9.6 \\
7.6-11.8\end{array}$ \\
\hline
\end{tabular}

$\mathrm{Q}_{1}=25$ th percentile; $\mathrm{Q}_{3}=75$ th percentile. 
Table 2 for women. EI tended to decrease with an increase in age in both men and women. In men the median EIs were $67 \%$ or less of the Recommended Dietary Allowance (RDA) ${ }^{15}$ while in women the median energy intakes were approximately $60 \%$ of the RDA. The EI : BMR ratios for men were 1.29, 1.18, 1.24, 1.19 and 0.84 for the different age categories and for women the figures were 1.28, 1.05, 0.99, 0.92 and 0.87 , respectively.

For the age groups 15-24, 25-34, 35-44, 45-54 and 55-69 years, median total protein intakes were 62.7, 66.5, 59.1, 58.6 and $42.1 \mathrm{~g}$ for men; and 48.5, 46.8, 42.2, 41.6 and $31.4 \mathrm{~g}$ for women, respectively. In the various age groups animal protein accounted for $46.3-63.7 \%$ of total protein intake. In both the men and women more than $30 \%$ of the energy consumed came from total fat. The medians for dietary $\mathrm{P}: \mathrm{S}$ ratios were high and varied between 1.09 and 1.77 in men and between 1.26 and 1.64 in women. Daily dietary cholesterol intake varied between 93 and $224 \mathrm{mg}$ in men and between 100 and $160 \mathrm{mg}$ in women. In all age groups median dietary fibre intakes were less than $17 \mathrm{~g}$ in men and less than $14 \mathrm{~g}$ in women. Median added sugar (sucrose) intakes were 71.6, 71.6, 64.1, 58.5 and $36.2 \mathrm{~g}$ for men and 52.8, $47.7,43.1,39.6$ and $35.6 \mathrm{~g}$ for women for the different age categories, respectively.

\section{Discussion}

Low EIs were found in the Indian population and the median EIs of men and women were below the RDA ${ }^{15}$. In men the median EIs were approximately two-thirds of the RDA but in women it was only about $60 \%$. When the 24-h dietary recall method is used for the collection of dietary data the sample size should be at least 50 per stratum $^{16}$. This was achieved in all groups except men and women 55-69 years of age, but some caution may be required in interpreting these results particularly the low median EIs. Since we wanted to compare our data with those of other South African studies we also reported mean EIs despite the skewness of the data. The mean EIs found in the CORIS ${ }^{10}$ study on white people and the Coronary Risk Factor Study on the Coloured Population (CRISIC) study ${ }^{11}$ were higher than in the Indian study. In the CORIS study the mean EIs for the different groups varied between 92 and $100 \%$ of the $\mathrm{RDA}$ in men and between 72 and $78 \%$ of the RDA in women. Similar figures for the CRISIC study were 79.8$85 \%$ for men and $71.5-101.9 \%$ for women. In the CORIS as well as the CRISIC studies the 24-h dietary recall method was used ${ }^{10,11}$. In agreement with the CORIS results, EI decreased with age but body mass index (BMI) increased with age. Especially in Indian women the dissociation between EI and obesity was prominent. Seedat et al. ${ }^{8}$ showed that $21.6 \%$ of the women, 15-69 years of age, had a BMI exceeding 30.
The age-adjusted figure was $17.5 \%$, using 1985 census figures for the Indian population of metropolitan Durban. Low physical activity has been observed in this population ${ }^{8}$.

Since the dietary methodology was not validated at the time of the study it is difficult to speculate on the reasons for the low EIs reported, but it could be due to under-reporting. The low EI : BMR ratios support the suspicion of under-reporting since in none of the groups the EI : BMR ratio was above 1.55 which is the requirement for a sedentary lifestyle ${ }^{14}$. Black et al. ${ }^{14}$ critically evaluated the EI data from published surveys and the EI : BMR ratios found in this study are in general lower than those reported. However, low EI: BMR ratios were also reported in the National Centre for Health Statistics (1979a,b) ${ }^{14}$, and the American 1971-74 study (National Health and Nutritional Examination Survey, NHANES) ${ }^{14}$, which also used the 24 -h recall. The study on Indian South Africans showed lower EI: BMR ratios for women than for men and also showed a decrease of the ratios with age which is in agreement with the results of the NHANES studies reported by Black et al. ${ }^{14}$

The median intake of protein by men $15-54$ years of age met the RDA for protein $(58-63 \mathrm{~g})$, however, the median intake of men older than 55 years of age did not meet this guideline which could be ascribed to the reasons mentioned above. The median protein intake of women 25 years and older did not meet the RDA for protein $(50 \mathrm{~g})$. In this study a smaller percentage, approximately $57 \%$, of protein was of animal origin compared to the Western diet ${ }^{10}$ in which approximately $70 \%$ of the total protein intake usually comes from animal sources. Pea flour, peas, black lentils and sugar beans, which are all good sources of plant protein, form an important part of many Indian dishes. The majority of the study population (576), are Hindus and vegetarianism is common amongst the Hindus ${ }^{17}$ but in this study only 11 subjects were vegetarians. Nevertheless, the relatively higher percentage of energy from plant protein compared to a Western $\operatorname{diet}^{10}$, indicates a more vegetable- and cereal-based diet in the subjects. In order to compensate for the possibility of underreporting, macronutrient intakes were mainly expressed as a percentage of EI instead of in absolute amounts. This showed that median protein intake met the prudent guideline of between 12 and 15\% of total EI, although it did not meet the RDA in some age categories. There are indications in the literature that the percentage of energy from protein decreases significantly with an increase in the EI : BMR ratio but in the present study there is only an indication of such a trend in $\operatorname{men}^{18}$.

An increase in the percentage of energy from fat with an increase in the EI : BMR ratio has been observed ${ }^{18}$, but not in the present study. Median total fat intake of both men and women exceeded the prudent dietary 
guideline of $30 \%$ of energy. The median total fat intake (approximately $35 \%$ of energy) of the Indians was approximately the same as the mean value (35.5\%) reported for white people studied in the South-Western Cape $^{10}$ and lower than the figure (37\%) reported for the 'coloured' urban population ${ }^{11}$ studied in the Cape Peninsula. The percentage of energy from fat in the diet of Indian South Africans is, however, higher than the figures reported for Punjabis in north-west India, where $20-25 \%$ of the energy comes from fat ${ }^{19}$. The prevalence of CHD is low in Punjabi Indians and the median serum cholesterol levels of men (3.90-4.68 $\mathrm{mmoll}^{-1}$ ) and women $\left(3.92-4.77 \mathrm{mmol}^{-1}\right.$ ) are also lower than those found by Seedat et al. ${ }^{8}$ for the Indian South African men $\left(4.75-6.28 \mathrm{mmol}^{-1}\right)$ and women $\left(4.73-6.09 \mathrm{mmol} \mathrm{l}^{-1}\right)$ on whom the dietary data was collected. The high total fat intake of Indian South Africans could in part explain the difference in CHD rates between these two Indian populations but it is important to note that the physical activity of the Punjabis is high and they do not smoke. It has also been shown that physical activity of South African Indians is probably low ${ }^{8}$. Seedat et al. ${ }^{8}$ reported that $41.9 \%$ of Indian South African men with a history of CHD smoked ten or more cigarettes a day.

A salient characteristic of the Indian diet was the high intake of polyunsaturated fatty acids, more than $10 \%$ of energy. The median dietary $\mathrm{P}: \mathrm{S}$ ratios of $1.09-1.77$ in men and 1.26-1.64 in women (mean 1.38-1.96 in men and 1.55-1.95 in women, unpublished data) were high compared to the mean values of 0.85 in the CRISIC study and 0.54 in the CORIS study. Sunflower oil is often used in the preparation of typical Indian foods which can explain the high $\mathrm{P}: \mathrm{S}$ ratio as well as the high vitamin $\mathrm{E}$ intake (20.0-25.7 $\mathrm{mg}$ in men; $16.8-23.3 \mathrm{mg}$ in women; unpublished data) of the study population.

In this study very high $\mathrm{P}: \mathrm{S}$ ratios were observed in those subjects who consumed a vegan-type diet with a curry sauce which had a high sunflower oil content. Miller et al. ${ }^{20}$ showed that in Britain the dietary P : S ratio (0.52) of Indians is twice as high as that of Europeans (0.26). The high dietary P : S ratio was also reflected in the fatty acid composition of the plasma phospholipids and C18:2n-6 was significantly higher in the Indians than in the Europeans studied by Miller et $\mathrm{al}^{20}$

The high intake of polyunsaturated fatty acids might be of concern in Indian South Africans. It has been shown by Bonanome etal. ${ }^{21}$ that the low-density lipoprotein (LDL) of human volunteers who followed a diet high in polyunsaturated fatty acids $30 \%$ of energy) is more prone to oxidation than those who followed a diet high in monounsaturated fatty acids (30\% of energy). There are indications that oxidized LDL is atherogenic in humans ${ }^{22}$. Vitamin $\mathrm{E}$ is an important antioxidant present in the LDL particle ${ }^{23}$ and in our study vitamin $\mathrm{E}$ intake (data not shown) was very high which could help to protect the LDL particle from oxidation. The potential of LDL to be oxidized is, however, more affected by the fatty acid composition of the LDL than by its antioxidant content ${ }^{21}$.

In all the different age categories for men and women, median cholesterol intakes were low and met the prudent recommendation of $300 \mathrm{mg}$ or less a day ${ }^{24}$.

The dietary fibre intakes of the men and the women were lower than the prudent dietary guideline ${ }^{24}$ of $20-$ $30 \mathrm{~g} \mathrm{day}^{-1}$ or $10 \mathrm{~g}$ per $4.2 \mathrm{MJ}$. In the CORIS as well as the CRISIC study figures for dietary intake of fibre were also low and were comparable to those found in the Indian study. The median sugar intakes of 58.5-71.6 g by men and women $15-54$ years in this study, are in agreement with a mean intake of $60-70 \mathrm{~g}$ found in a study in India ${ }^{19}$. Albertse et $^{2}{ }^{25}$ reported a median sucrose intake of $80 \mathrm{~g}$ for an Indian community of men and women 11-41 years and older residing in Cape Town.

Evaluation of risk factors other than diet indicated that the prevalence of hypertension is lower in Indian ${ }^{8}$ than in white ${ }^{26}$ and "coloured" ${ }^{27}$ South Africans. Smoking, however, seems to be an important risk factor since it was reported that $41.9 \%$ of Indian men ${ }^{8}$ compared to $39.0 \%$ of 'coloured ${ }^{27}, 33.4 \%$ of white ${ }^{26}$ and $24.7 \%$ of black ${ }^{28}$ South African men smoked ten or more cigarettes a day. Although obesity was present in $21.6 \%{ }^{8}$ of women this figure is much lower than the figure of $44.4 \%{ }^{28}$ reported for black South African women in whom the prevalence of CHD is low. Obesity does not seem to be a problem, at least at present, in Indian men with only $3.2 \%$ reported to be obese. Diabetes mellitus was present in about $16 \%$ of Indian South Africans studied by Seedat et $a l^{8}$ A high prevalence of diabetes mellitus in Indians has also been reported in the $\mathrm{UK}^{29}$ but it is believed that the prevalence of diabetes mellitus is lower in Indians from India ${ }^{30}$.

It has been known for some time that Indians who live outside India have a higher prevalence of CHD than their counterparts living in their native country and this is also true for Indian South Africans ${ }^{1}$. This study has shown that the diet could contribute to the risk profile because it has elements of a typical Western diet, although elements of a prudent diet were also seen. The energy distribution for total fat intake and dietary fibre intakes of Indian South Africans were typical of a Western diet, dietary cholesterol intake and the $\mathrm{P}: \mathrm{S}$ ratio of the diet were, however, more in agreement with the guidelines for a prudent diet. Singh et al. reported higher lipid peroxides in Indians with CHD, diabetes and those who smoked ${ }^{31}$. The very high $\mathrm{P}: \mathrm{S}$ ratio of the diet of Indian South Africans is therefore of special concern and the effect of this high dietary $\mathrm{P}: \mathrm{S}$ ratio on the oxidation of LDL should be investigated as a possible contributing risk factor for CHD in this population group. 
The aetiology is clearly multifactorial. This study and Seedat $\mathrm{et} \mathrm{al} .{ }^{8}$ confirmed that many risk factors for CHD were present in Indian South Africans. In this population group, the diet with its Western elements is probably one of the important risk factors for CHD. Annual age-specific mortality rates for $\mathrm{CHD}$ changed from $110 / 100,000$ in 1985 to $96 / 100000$ in $1989^{1}$. The decline in mortality rates were $15.2 \%$ in men and $8.4 \%$ in women ${ }^{1}$. Due to a lack of information, one cannot say whether changes in dietary intakes could have contributed to this. There is definitely a need to determine what the contribution of the diet was to the incidence of $\mathrm{CHD}$ in the study population during the past decade. The present study indicated a need for changes in lifestyle and also showed that specific elements of the diet may carry a risk in terms of the development of CHD, especially the high $\mathrm{P}: \mathrm{S}$ ratio of the diet. Only through re-evaluation of the study population will we be able to determine whether or not the necessary changes have taken place during the past decade and if there is a need to address the dietary inadequacies through appropriate nutrition intervention programmes.

\section{Acknowledgement}

The authors wish to thank Miss M Lyle, Department of Nutrition, University of Durban-Westville, for assistance in quantifying the Indian food diet items used in the preparation of various Indian dishes.

\section{References}

1 Anon. Ischaemic heart disease mortality in South Africa, 1985-1989. Epidemiol. Comments 1992; 19: 147-53.

2 Marmot MG, Adelstein AM, Bulusi L. Immigrant Mortality in England and Wales, 1970-1978. London: HMSO, 1984.

3 Balarajan R, Bulusu L, Adelstein AM, Shukla V. Patterns of mortality among migrants to England and Wales from the Indian subcontinent. Br. Med. J. 1984; 289: 1185-7.

4 Malhotra SL. Epidemiology of ischaemic heart disease in India with special reference to causation. Br. Heart J. 1967; 29: 895-905.

5 Mathur KS. Environmental factors in coronary heart disease. Circulation 1960; 21: 684-9.

6 Padmavati S. Epidemiology of cardiovascular disease in India. II. Ischemic heart disease. Circulation 1962; 25: 71117.

7 Bhatia ML. Prevalence of coronary heart disease in India: a contemporary view. Indian Heart J. 1995; 47: 339-42.

8 Seedat YK, Mayet FGH, Khan S, Somers SR, Joubert G. Risk factors for coronary heart disease in the Indians of Durban. S. Afr. Med.J. 1990; 78: 447-54.

9 Omar MAK, Seedat MA, Dyer RB, Rajput MC, Motala AA, Joubert SM. The prevalence of diabetes mellitus in a large group of South African Indians. S. Afr. Med.J. 1985; 67: $924-$ 6.

10 Wolmarans P, Langenhoven ML, Benadé AJS, Swanepoel ASP, Kotze TJvW, Rossouw JE. Intake of macronutrients and their relationship with total cholesterol and high-density lipoprotein cholesterol. The Coronary Risk Factor Study, 1979. S. Afr. Med. J. 1988; 73: 12-15.

11 Langenhoven ML, Steyn K, van Eck M, Gouws E. Nutrient intake in the coloured population of the Cape Peninsula Eco. Food Nutr. 1988; 22: 97-106

12 Gouws E, Langenhoven ML. NRIND Food Composition Tables 1986, second edition. Parow: South African Medical Research Council, 1986.

13 Schofield WN. Predicting basal metabolic rate, new standards and review of previous work. Hum. Nutr. Clin. Nutr 1985; 39C(suppl 1): 5-41.

14 Black AE, Goldberg GR, Jebb SA, Livingstone MBE, Cole TJ, Prentice AM. Critical evaluation of energy intake data using fundamental principles of energy physiology. 2. Evaluating the results of published surveys. Eur. J. Clin. Nutr. 1991; 45 583-99.

15 Food and Nutrition Board. Commission on Life Sciences National Research Council. Recommended Dietary Allowances, 10th edition. Washington, DC: National Academy Press, 1989.

16 Block G. A review of validations of dietary assessment methods. Am. J. Epidemiol. 1982; 115: 492-505.

17 Frank MdV. Cultural differences in eating habits of SA Indians. J. Diet. Home Econ. 1982; 10: 58-61.

18 Voss S, Kroke A, Klipstein-Grobusch K, Boeing H. Is macronutrient composition of dietary intake data affected by underreporting? Results from the EPIC-Potsdam study. Eur. J. Clin. Nutr. 1998; 52: 119-26.

19 Werner GT, Sareen DK. Serum cholesterol levels in the population of Punjab in north west India. Am.J. Clin. Nutr. 1978; 31: 1479-83.

20 Miller GJ, Kotecha S, Wilkinson WH et al. Dietary and other characteristics relevant for coronary heart disease in men of Indian, West Indian and European descent in London. Atherosclerosis 1988; 70: 63-72.

21 Bonanome A, Pagnan A, Biffanti S et al. Effect of dietary monounsaturated and polyunsaturated fatty acids on the susceptibility of plasma low density lipoproteins to oxidative modification. Arterioscl. Thromb. 1992; 12: 529-33.

22 Regnström J, Nilsson J, Tornvall P, Landou C, Hamsten A. Susceptibility to low-density lipoprotein oxidation and coronary atherosclerosis in man. Lancet 1992; 339: 1183-6.

23 Ogihara T, Miki M, Kitagawa M, Mino M. Distribution of tocopherol among human plasma lipoproteins. Clin. Chim. Acta 1988; 174: 299-305.

24 Diet Consensus Panel. Dietary recommendations for the prevention of coronary heart disease. Statement by the Diet Consensus Panel. S. Afr. Med.J. 1989; 76: 591-2.

25 Albertse EC, Hugo M, van Wyk CW. Sucrose intake of an Indian community residing in Cape Town. J. Diet. Home Econ. 1978; 6: 89-92.

26 Rossouw JE, Du Plessis JP, Benadé AJS, Jordaan PCJ, Kotzé JP, Jooste PL, Ferreira JJ. Coronary risk factor screening in three rural communities. The CORIS baseline study. S. Afr. Med.J. 1983; 64: 430-6.

27 Steyn K, Jooste PL, Langenhoven ML et al. Coronary risk factors in the coloured population of the Cape Peninsula. $S$. Afr. Med.J. 1985; 67: 619-25.

28 Steyn K, Jooste PL, Bourne L et al. Risk factors for coronary heart disease in the black population of the Cape Peninsula The BRISK study. S. Afr. Med.J. 1991; 79: 480-5.

29 Mather HM, Keen H. The Southhall diabetes survey: prevalence of known diabetes in Asians and Europeans. Br. Med.J. 1985; 291: 1081-4.

30 Ahuja MMS. Epidemiological Survey on Diabetes Mellitus in India. New Delhi: Interprint, 1979; 29-38.

31 Singh RB, Ghosh S, Niaz MA et al. Dietary intake, plasma levels of antioxidant vitamins, and oxidative stress in relation to coronary artery disease in elderly subjects. $\mathrm{Am}$. J. Cardiol. 1995; 76: 1233-8. 